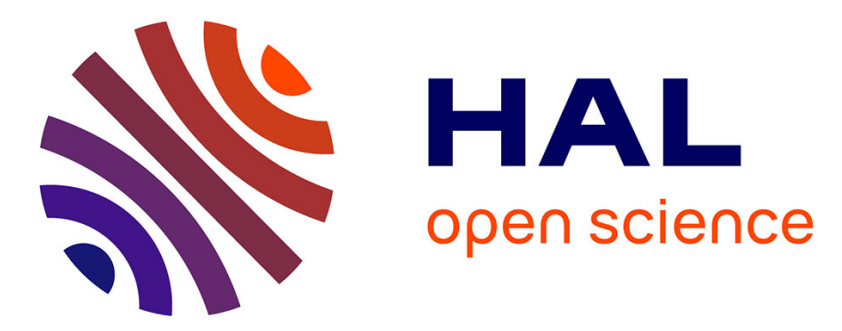

\title{
Synthesis, Characterization, and Electrochemical Study of Complexes with 4,4'-Bis(Salicylideneimino) Diphenylether and Cobalt(II), Copper(II), Zinc(II), and Cadmium(II)
}

S. Issaadi, D. Haffar, T. Douadi, S. Chafaa, D. Séraphin, Mustayeen A. Khan, Gilles Bouet

\section{To cite this version:}

S. Issaadi, D. Haffar, T. Douadi, S. Chafaa, D. Séraphin, et al.. Synthesis, Characterization, and Electrochemical Study of Complexes with 4,4'-Bis(Salicylideneimino) Diphenylether and Cobalt(II), Copper(II), Zinc(II), and Cadmium(II). Synthesis and Reactivity in Inorganic, Metal-Organic, and Nano-Metal Chemistry, 2005, 35 (10), pp.875-882. 10.1080/15533170500358044 . hal-03227305

\section{HAL Id: hal-03227305 \\ https://univ-angers.hal.science/hal-03227305}

Submitted on 19 May 2021

HAL is a multi-disciplinary open access archive for the deposit and dissemination of scientific research documents, whether they are published or not. The documents may come from teaching and research institutions in France or abroad, or from public or private research centers.
L'archive ouverte pluridisciplinaire HAL, est destinée au dépôt et à la diffusion de documents scientifiques de niveau recherche, publiés ou non, émanant des établissements d'enseignement et de recherche français ou étrangers, des laboratoires publics ou privés. 


\title{
Synthesis, Characterization, and Electrochemical Study of Complexes with 4,4'-Bis(Salicylideneimino) Diphenylether and Cobalt(III), Copper(II), Zinc(II), and Cadmium(III)
}

\author{
S. Issaadi, D. Haffar, T. Douadi, and S. Chafaa \\ Laboratoire d'Electrochimie des Matériaux Moléculaires et Complexes, Département de Génie des \\ Procédés, Faculté des Sciences de l'Ingénieur, Université Ferhat Abbas, Sétif, Algéria
}

D. Séraphin, M. A. Khan, and G. Bouet

SONAS, EA 921, Université d'Angers, Faculté de Pharmacie, Angers Cedex, France

The 4,4'-bis(salicyleneimino) diphenyl ether is a $\mathrm{N}_{2} \mathrm{O}_{3}$ Schiff base but it acts as a tetradentate ligand. Its complexes with cobalt (II), copper(II), zinc(II), and cadmium (II) were characterised using spectroscopic determinations, d.s.c. and cyclic voltammetry. In these compounds, the coordination occurs through the non-ionised phenolic hydroxyl of the ligand and the nitrogen atom of the azomethine moiety. These new complexes should be formulated $\left[\mathrm{CuCl}_{2}\left(\mathrm{H}_{2} \mathrm{~L}\right)\right] \cdot \mathrm{H}_{2} \mathrm{O}, \quad\left[\left(\mathrm{CoCl}_{2}\right)_{2}\left(\mathrm{H}_{2} \mathrm{~L}\right)\left(\mathrm{H}_{2} \mathrm{O}\right)_{4}\right] \cdot 2 \mathrm{H}_{2} \mathrm{O}$, $\left[\mathrm{Zn}_{2} \mathrm{Cl}_{2}\left(\mathrm{H}_{2} \mathrm{~L}\right)\right]$ and $\left[\mathrm{Cd}\left(\mathrm{H}_{2} \mathrm{~L}\right)\right] \mathrm{Cl}_{2}$ respectively. The copper(II) and cadmium(II) complexes are mononuclear while the cobalt(II) and zinc(II) appeared to be binuclear species. The anodic oxidations of cobalt (II), zinc(II), and cadmium(II) compounds show only one peak attributed to the oxidation of the phenolic moiety of the ligand. In addition, the copper complex $\left[\mathrm{CuCl}_{2}\left(\mathrm{H}_{2} \mathrm{~L}\right)\right] \cdot \mathrm{H}_{2} \mathrm{O}$ exhibits two peaks at $+680 \mathrm{mV}$ (ECS) and $+965 \mathrm{mV}$ (ECS) corresponding to the complexed couples $\mathrm{Cu}^{\mathrm{II}} / \mathrm{Cu}^{\mathrm{III}}$ and $\mathrm{Cu}^{\mathrm{I}} / \mathrm{Cu}^{\mathrm{II}}$.

Keywords Complexes, cyclic voltammetry, Schiff base, tetradentate

\section{INTRODUCTION}

Among metal complexes, Schiff bases coordination compounds showing an imino moiety in their structure were widely used in medicine, for corrosion prevention, metal recovery, as well as to treat nuclear wastes. As these bases

Received 4 July 2005; accepted 9 September 2005.

This work was partly supported by grants from the Comité Mixte d'Évaluation et de Prospective de coopération interuniversitaire franco-algérienne (CMEP).

Address correspondence to Gilles Bouet, SONAS, EA 921, Université d'Angers, Faculté de Pharmacie, 16 Boulevard Daviers, Angers Cedex 01, F-49045, France. E-mail: gilles.bouet@univ. angers.fr show a great ability to complex many metal ions, they also may be useful for water treatment (Wilkinson, 1987).

Since the pioneering work of (Feiffer et al., 1933) a large series of Schiff bases coordination compounds was described. More recently, (Yudhvir et al., 1994) have published the synthesis and the characterisation of bis(2,5-dihydroxyacetophenone ethylenediamine (daen), a tetradentate Schiff base, and of its monomeric and dimeric copper(II) complexes. In both cases, the cupric ion showed a tetrahedral arrangement binding through $\mathrm{O}$ and $\mathrm{N}$ atoms of the ligand.

S. Samal et al. (2002) have prepared Schiff's bases resins by reacting o-hydroxyacetophenone 4,4'-diamino diphenylether with successively ethanal and 2-furaldehyde. They were able to isolate copper (II) from a mixture of $\mathrm{Cu}$ (II) and $\mathrm{Ni}(\mathrm{II})$ ions. Starting from 4,4-bis[2-(aminomethyl) pyridylisonitrosoacetyl]diphenylmethane and 4,4-bis(2-hydroxy-5-methylphenylaminoisonitrilrosoacetyl)diphenylmethane, (Karipcin et al., 2002) obtained a series of complexes with $\mathrm{Co}(\mathrm{II})$, $\mathrm{Ni}$ (II), and $\mathrm{Cu}(\mathrm{II})$. The phenolic hydroxyl was not deprotonated in the case of $\mathrm{Ni}(\mathrm{II})$ complex, which is a mononuclear species. The binuclear complexes with cobalt and copper are coordinated through deprotonated phenolic hydroxyl.

Two heptadentate ligands were described (Keypour et al., 2002): the ligand tris(3-salicylidenimino) propylamine and tris(3-(4'-hydroxysalicylideneimino)-propyl)amine coordinated through the three phenolic hydroxyls, but two of them were ionised. All these complexes were insoluble in aqueous media. (Keypour et al., 2003, 2004) reported the coordination of zinc(II) and magnesium(II) by macrocyclic heptaaza Schiff-base with two aminoethyl pendant arms.

The tetradentate ligands 4,4'-bis(salicylideneimino)diphenylmethane (sal-dadpmX) lead to complexes of general formula: $\left.\left[\mathrm{M}_{2} \text { (sal-dadpmX }\right)_{2}\right]$ where $\mathrm{X}=\mathrm{H}, \mathrm{CH}_{3}, \mathrm{OCH}_{3}, \mathrm{Cl}$ and $\mathrm{M}=\mathrm{Cu}(\mathrm{II}), \mathrm{Ni}(\mathrm{II}), \mathrm{Co}(\mathrm{II})$, dioxoranium(VI) (Ramachandraiah et al., 1989). While the copper(II) complexes were found to 
<smiles>Oc1ccccc1/C=N/c1ccc(Oc2ccc(/N=C/c3ccccc3O)cc2)cc1</smiles>

FIG. 1. Chemical structure of the ligand $\mathrm{H}_{2} \mathrm{~L}$.

be pseudotetrahedral species, the $\mathrm{Co}(\mathrm{II}), \mathrm{Ni}(\mathrm{II})$ and dioxoranium(VI) exhibited an octahedral geometry. Tetradentate Schiff base ligands deriving from 4-aminoantipyrine and 2-aminophenol or 2-aminothiophenol chelated $\mathrm{Cu}(\mathrm{II}), \mathrm{Ni}(\mathrm{II})$, $\mathrm{Co}(\mathrm{II}), \mathrm{Mn}(\mathrm{II}), \mathrm{Zn}(\mathrm{II})$ and $\mathrm{Vo}(\mathrm{II})$ ions. The corresponding complexes exhibited a higher antimicrobial activity than the ligands alone (Raman, 2001).

(Ando et al., 2004) have recently reported the characterisation of a series of pentadentate Schiff base derived from salicylaldehyde and their complexes with oxovanadium(IV).

In this paper, we report the synthesis and the characterisation of new complexes with $\mathrm{Co}(\mathrm{II}), \mathrm{Cu}(\mathrm{II}), \mathrm{Zn}(\mathrm{II})$ and Cd(II) of a tetradentate Schiff base: $4,4^{\prime}$-bis(salicyleneimino) diphenyl ether $\left(\mathrm{H}_{2} \mathrm{~L}\right)$ whose structure is given on Figure 1. Their electrochemical behaviour in organic media is described

\section{RESULTS AND DISCUSSION}

The main analytical data are given in Table 1. The copper (II) compound synthesised as described above, differs from the complex obtained by (Yoshida et al., 1999) in DMF as solvent, which was found to be a polymeric species $[\mathrm{CuL}]_{n}$ The spectral data of our complexes is summarised in Table 2.

\section{Infrared Spectra}

In the ligand and in all complexes the phenolic $\mathrm{O}-\mathrm{H}$ stretching vibration is located between 3500 and $3100 \mathrm{~cm}^{-1}$. Some differences are observed: in the spectrum of the ligand $\mathrm{H}_{2} \mathrm{~L}$ (1) the low intensity band located at $3444 \mathrm{~cm}^{-1}$ is narrow. The spectrum of the complex (2) exhibits a very large and intense band with a maximum at $3407 \mathrm{~cm}^{-1}$. This band is unsymmetrical in the case of the copper complex (3) with small shoulders at lower wavenumbers. The zinc compound (4) shows a smaller band around $3440 \mathrm{~cm}^{-1}$ and in the case of the cadmium(II) compound (5) this band is shifted to $3483 \mathrm{~cm}^{-1}$.

As expected, the aromatic ring vibrations are not modified when passing from ligand to complexes. The stretching vibration band of the $\mathrm{C}=\mathrm{N}$ bond is observed at c.a. $1620 \mathrm{~cm}^{-1}$ as a single sharp band in the case of the ligand (1) and the complex (3). In the other spectra, this band appears with one or two close shoulders. This indicates that the nitrogen atoms of the two azomethine groups are coordinating atoms.

The stretching vibration band of the ether moiety remained unchanged in the whole series. Consequently, this oxygen atom is not involved in the coordination and the 4,4'-bis(salicyleneimino) diphenyl ether $\mathrm{H}_{2} \mathrm{~L}$ acts as a tetradentate ligand.

\section{${ }^{1}$ H-N.M.R. Spectra}

The ${ }^{1} \mathrm{H}$ n.m.r. spectrum of the ligand (Table 2) shows the singulet corresponding to the two phenolic protons at 13.3 p.p.m. (Sanmartin et al., 2000). In the case of the diamagnetic $\mathrm{Zn}(\mathrm{II})$ and $\mathrm{Cd}(\mathrm{II})$ compounds we note that this signal is slightly shifted down due to complexation. In the mean time, we note that the peak of the proton relative to $\mathrm{CH}-\mathrm{N}$ group is slightly shifted to higher values. These observations are in agreement with the structures proposed for the corresponding complexes.

\section{Thermal Analysis}

The d.s.c. data is reported in Table 3. The melting point of the ligand (1), with a very thin symmetric endothermic peak, is observed at $212^{\circ} \mathrm{C}$.

The d.s.c. diagram of the compound (2) presents a very weak endothermic peak at $159^{\circ} \mathrm{C}$ followed by an important unsymmetrical endotherm at $188^{\circ} \mathrm{C}$, a feeble endotherm at $217^{\circ} \mathrm{C}$ and finally a strong endothermic peak at $241^{\circ} \mathrm{C}$. The first peak corresponds to the departure of the unbounded water molecules. In the same experimental conditions, the hexahydrated cobalt(II) chloride exhibits a wide endothermic peak at c.a. $185^{\circ} \mathrm{C}$ due to loss of coordinated water molecules.

TABLE 1

Analytical data

\begin{tabular}{|c|c|c|c|c|c|c|c|}
\hline Compounds & & $\begin{array}{c}\text { Yield } \\
(\%)\end{array}$ & Color & $\begin{array}{l}\text { M.P. } \\
\left({ }^{\circ} \mathrm{C}\right)\end{array}$ & C \% (cald.) & $\mathrm{H} \%$ & $\mathrm{~N} \%$ \\
\hline Ligand $\left(\mathrm{H}_{2} \mathrm{~L}\right)$ & $(1)$ & 90 & Yellow & 212 & $76.4(76.5)$ & $4.6(4.9)$ & $7.0(6.9)$ \\
\hline$\left[\left(\mathrm{CoCl}_{2}\right)_{2}\left(\mathrm{H}_{2} \mathrm{~L}\right)\left(\mathrm{H}_{2} \mathrm{O}\right)_{4}\right] \cdot 2 \mathrm{H}_{2} \mathrm{O}$ & $(2)$ & 40 & Green & $>260 \mathrm{~d}$ & $39.5(40.2)$ & $4.9(4.2)$ & $3.6(3.6)$ \\
\hline$\left[\mathrm{CuCl}_{2}\left(\mathrm{H}_{2} \mathrm{~L}\right)\right] \cdot \mathrm{H}_{2} \mathrm{O}$ & (3) & 40 & Brown & $>240 \mathrm{~d}$ & $57.4(55.7)$ & $3.9(3.9)$ & $6.0(5.0)$ \\
\hline$\left[\mathrm{Zn}_{2} \mathrm{Cl}_{2}\left(\mathrm{H}_{2} \mathrm{~L}\right)\right]$ & (4) & 45 & Orange & $>260 \mathrm{~d}$ & $51.7(51.2)$ & $3.7(3.3)$ & $4.7(4.6)$ \\
\hline$\left[\mathrm{Cd}\left(\mathrm{H}_{2} \mathrm{~L}\right)\right] \mathrm{Cl}_{2}$ & (5) & 70 & Orange & $>260 \mathrm{~d}$ & $52.2(52.2)$ & $3.4(3.4)$ & $4.8(4.7)$ \\
\hline
\end{tabular}

d: decomposition. 
TABLE 2

Spectral data

\begin{tabular}{|c|c|c|c|c|c|c|}
\hline Compound & & (1) & (2) & (3) & (4) & (5) \\
\hline \multirow[t]{9}{*}{ I.R. spectra ${ }^{a}$} & Vibration & & & & & \\
\hline & $v(\mathrm{OH})$ & 3444 w & $3407 b$ & 3448 & 3443 & 3483 \\
\hline & Benzene rings & 3053 & 3065 & 3050 & 3064 & 3056 \\
\hline & & 835 & 836 & 835 & 837 & 833 \\
\hline & & 750 & 750 & 750 & 759 & 749 \\
\hline & $\nu(\mathrm{C}-\mathrm{N})$ & 1621 & 1620 & 1620 & 1633 & 1619 \\
\hline & $\delta(\mathrm{OH})$ & 1263 & 1262 & 1262 & 1252 & 1260 \\
\hline & $v(\mathrm{C}-\mathrm{O})$ & 1283 & 1283 & 1283 & - & 1283 \\
\hline & $v(\mathrm{C}-\mathrm{N})$ & 1189 & 1188 & 1188 & 1178 & 1188 \\
\hline \multirow[t]{4}{*}{ NMR ${ }^{1} \mathrm{H}$ spectra ${ }^{b}$} & Chemical shift & & & & & \\
\hline & H phenol & $13.3 \mathrm{~s}$ & - & - & 13.1 & 13.1 \\
\hline & $\mathrm{CH}=\mathrm{N}$ & 8.7 & - & - & 9.0 & 9.0 \\
\hline & $\mathrm{H}$ aromatic & $7.5-6.9$ & - & - & $7.7-6.6$ & $7.7-6.9$ \\
\hline
\end{tabular}

${ }^{a} \mathrm{KBr}$ disk, $\mathrm{cm}^{-1} ; \mathrm{b}=$ boad, $\mathrm{w}=$ weak, $\mathrm{sh}=$ shoulder.

${ }^{b}$ Chemical shift in ppm (TMS); $\mathrm{s}=$ singulet.

The same phenomenon is observed in the case of the complex (2) for the endotherm at $188^{\circ} \mathrm{C}$. The last exothermic peak is due to the decomposition of the molecule.

In the case of the copper complex (3), the first exothermic peak at $133^{\circ} \mathrm{C}$ is due to the release of the water molecules as previously described (Haffar, 2004; Bouet et al., 1996). The

\section{TABLE 3}

\begin{tabular}{lcc}
\multicolumn{3}{c}{ D.s.c. data } \\
\hline Compound & $\begin{array}{c}\text { Peaks } \\
\left({ }^{\circ} \mathrm{C}\right)\end{array}$ & $\begin{array}{c}\Delta H \\
\left(\mathrm{~kJ} \cdot \mathrm{mol}^{-1}\right)\end{array}$ \\
\hline$(1)$ & 212 & +55 \\
$(2)$ & 159 & +3 \\
& 188 & +144 \\
& 217 & +4 \\
$(3)$ & 241 & +122 \\
& 133 & -71 \\
& 214 & +14 \\
$(4)$ & 284 & -42 \\
& 323 & +63 \\
$(5)$ & 330 & -178 \\
& 209 & +29 \\
$\mathrm{CoCl}_{2} \cdot 6 \mathrm{H}_{2} \mathrm{O}$ & 382 & +24 \\
& 62 & -125 \\
$\mathrm{CuCl}_{2} \cdot 2 \mathrm{H}_{2} \mathrm{O}^{a}$ & 185 & endo \\
& 138 & -133 \\
& 185 & +30.7 \\
\hline
\end{tabular}

${ }^{a}$ From reference Haffar et al. (2004) and Bouet et al. (1996). other peaks, due to its decomposition, are observed at $214^{\circ} \mathrm{C}$ (endothermic) and $284^{\circ} \mathrm{C}$ (very large exotherm).

The zinc complex (4) is stable until $320^{\circ} \mathrm{C}$. A narrow endothermic peak is observed at $323^{\circ} \mathrm{C}$, followed immediately by an exothermic one at $330^{\circ} \mathrm{C}$. The first is due to the breaking of the binuclear species and the second to a decomposition process.

Finally, the d.s.c. diagram of the cadmium complex (5), shows two peaks located at $209^{\circ} \mathrm{C}$ and $382^{\circ} \mathrm{C}$ showing a weak endothermic effect. The first is unsymmetrical with a shoulder at the beginning due to the break of the coordination bonds and the melting of the free ligand.

\section{Cyclic Voltammetry}

The cyclic voltammograms were recorded at $25 \pm 0.2^{\circ} \mathrm{C}$ in $\mathrm{DMF}$ and the ionic strength was maintained at $0.1 \mathrm{~mol} \cdot \mathrm{L}^{-1}$ with $\mathrm{Et}_{4} \mathrm{NClO}_{4}$ (TEAP) as supporting electrolyte. The data are reported in Table 4 and the voltammograms are given in Figure 2.

The cyclic voltammetric study of $\mathrm{H}_{2} \mathrm{~L}$ (1) from $+1700 \mathrm{mV}$ to $-1600 \mathrm{mV}$ (vs. SCE) shows an anodic peak at $+1180 \mathrm{mV}$ and a cathodic one at $-1020 \mathrm{mV}$. The oxidation peak corresponds to the oxidation of the phenolic group, while the second peak is attributed to the reduction of the imine moiety (Gili et al., 1996). During the second sweep, the reduction of the oxidised phenolic group occurs at $+400 \mathrm{mV}$.

During a sweep from -1600 to $+1700 \mathrm{mV}$, the cobalt compound (2) exhibits a cathodic peak at $-1270 \mathrm{mV}$ and two anodic peaks at -150 and $+1330 \mathrm{mV}$ respectively. When the scan is limited from 0 to $-1000 \mathrm{mV}$, the first anodic peak at $-150 \mathrm{mV}$ is absent and consequently this 
TABLE 4

Voltamperometric results in DMF at $25^{\circ} \mathrm{C}$, ionic strength $0.1 \mathrm{~mol} \cdot \mathrm{L}^{-1}$ (TEAP), results in $\mathrm{mV}$ vs $\mathrm{SCE}, E_{\mathrm{a}}$ : anodic; $E_{\mathrm{c}}$ : cathodic

\begin{tabular}{|c|c|c|c|c|c|}
\hline \multirow[b]{2}{*}{ Compound } & \multirow[b]{2}{*}{ Sweep } & \multicolumn{2}{|c|}{ Oxidation } & \multicolumn{2}{|c|}{ Reduction } \\
\hline & & $E_{\mathrm{pa}}(\mathrm{mV})$ & $E_{\mathrm{pc}}(\mathrm{mV})$ & $E_{\mathrm{pa}}(\mathrm{mV})$ & $E_{\mathrm{pc}}(\mathrm{mV})$ \\
\hline \multirow[t]{2}{*}{ (1) } & 1 & +1480 & & & -1020 \\
\hline & 2 & & & & -400 \\
\hline \multirow[t]{2}{*}{ (2) } & 1 & +1330 & & -150 & -1270 \\
\hline & 2 & & -400 & & \\
\hline \multirow[t]{2}{*}{ (3) } & 1 & $\begin{array}{l}+1460 \\
+960 \\
+680 \\
+210\end{array}$ & +380 & -140 & -1450 \\
\hline & 2 & & & & -600 \\
\hline \multirow[t]{2}{*}{ (4) } & 1 & +1570 & & -670 & -900 \\
\hline & 2 & & & & -110 \\
\hline \multirow[t]{2}{*}{ (5) } & 1 & +1560 & & -340 & $\begin{array}{l}-1400 \\
-1080\end{array}$ \\
\hline & 2 & & & & -250 \\
\hline
\end{tabular}

peak corresponds to the reoxidation of the phenolic reduced species obtained at $-1270 \mathrm{mV}$. The following sweeps $(-1600$ to $+1700 \mathrm{mV})$ show a new peak at $-400 \mathrm{mV}$ with growing intensity. Under similar experimental conditions, $\mathrm{CoCl}_{2}$ shows a cathodic peak at $-1500 \mathrm{mV}$ (SCE) and an anodic one at $-100 \mathrm{mV}$ (Djebbar-Sid et al., 2001).

The copper(II) complex (3) shows two cathodic peaks at -1450 and $380 \mathrm{mV}$ and five anodic peaks located at -140 , $+210,+680,+960$ and $+1460 \mathrm{mV}$ respectively. The anodic peaks at +680 and $960 \mathrm{mV}$ correspond to the oxidation of the cupric ions (Djebbar-Sid et al., 2001; Gullotti et al., 1972; Fernandez-G et al., 2002; Pereira et al., 1998; Nicholson and Schain, 1964; Djebbar-Sid et al., 1997). A new study between 0 to $+750 \mathrm{mV}$ shows that the peak at $380 \mathrm{mV}$ is due to the reduction of the previously oxidised copper(III) (Raman et al., 2001). When several sweeps between $-1600 \mathrm{mV}$ and $+1700 \mathrm{mV}$ are performed successively, we note that the intensities of the peaks located at -1450 and $+210 \mathrm{mV}$ are diminishing. It is well known that the $\mathrm{Cu}^{\mathrm{II}} / \mathrm{Cu}^{\mathrm{I}}$ reaction in most $\mathrm{CuN}_{2} \mathrm{O}_{2}$ coordination complexes is quasireversible in nature due to the fact that the [Cu $\left.{ }^{\mathrm{I}} \mathrm{L} 2\right]$ species are chemically decomposed to a copper ion (reaction 1), which subsequently is reduced to copper metal (AguilarMartinez et al., 2001).

$$
\left.\left[\mathrm{Cu}^{1}(\mathrm{HL})\right] \rightleftharpoons \mathrm{Cu}^{+}+\mathrm{HL} \rightleftharpoons \mathrm{Cu}^{0}+\mathrm{HL} \quad \text { (reaction } 1\right)
$$

Finally, a new sweep, limited from -1000 to $+1000 \mathrm{mV}$ leads to the disappearing of two peaks at -140 and $+210 \mathrm{mV}$, respectively. These two peaks are due to the reoxidation of the species obtained from the phenolic moiety at $-1450 \mathrm{mV}$ (Samal et al., 2002; Raman et al., 2001; Gullotti et al., 1972; Anderson et al., 1984).

A scan in the range 0 to $-1600 \mathrm{mV}$ in the case of the compound (4) with zinc, shows a reduction cathodic peak at $-900 \mathrm{mV}$ and an anodic peak at $-670 \mathrm{mV}$ due to the oxidation of the metallic zinc previously formed. A new scan from 0 to $+1700 \mathrm{mV}$ leads to a single anodic peak at $+1570 \mathrm{mV}$ (phenol group oxidation). Successive sweeps from $-1660 \mathrm{mV}$ to $+1700 \mathrm{mV}$ show the appearance of a new cathodic peak at $-110 \mathrm{mV}$, which results of the reoxidation of the reduced phenolic group. In this cyclic voltammograms, the oxidation curve and the reduction one cross over; this may be due to the deposition of reduced material on the surface of the electrode (Yudhuir et al., 1994) and to the presence of bridging chloride in the structure of this binuclear complex. A similar behaviour with very poorly defined peaks was observed in some zinc complexes obtained from Schiff bases (Lutta and Kagwanja, 2001).

Finally, in the range -1600 to $+1700 \mathrm{mV}$, the cyclic voltammogram of the cadmium complex (5) exhibits two cathodic peaks: $-1400 \mathrm{mV}$ and $-1080 \mathrm{mV}$ and two anodic peaks at $-340 \mathrm{mV}$ and $+1560 \mathrm{mV}$. The peak corresponds to the oxidation of the phenolic part of the Schiff base. at A second sweep shows that the peak at $-1400 \mathrm{mV}$ is absent and that the two peaks at $-1080 \mathrm{mV}$ and $-340 \mathrm{mV}$ are slightly shifted to higher potential values; in the mean time, their intensities decrease because of a partial blocking of the electrode (Nicholson and Schain, 1964). 




Ligand (1)

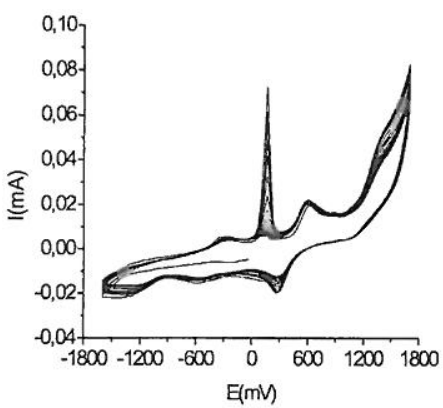

Copper complex (3)

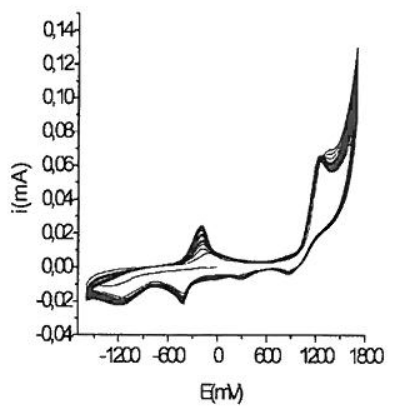

Cobalt complex (2)

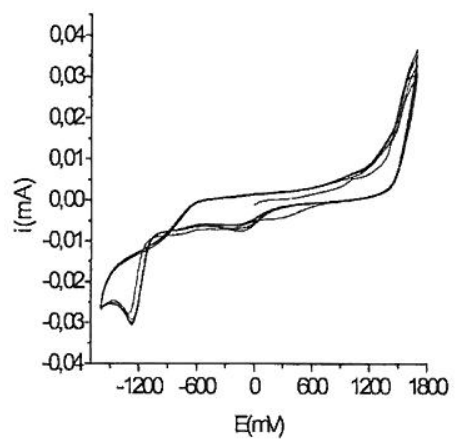

Zinc complex (4)

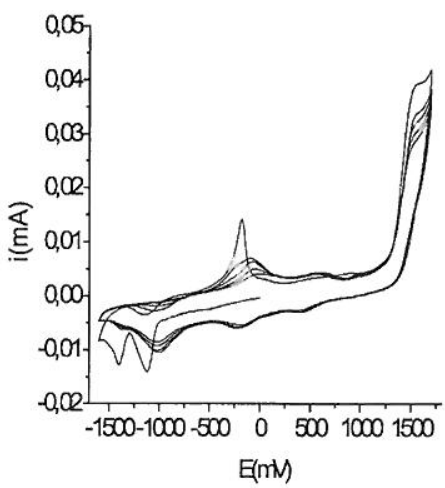

Cadmium complex (5)

FIG. 2. Cyclic voltammograms.

\section{Proposed Structures}

Though the ligand $\mathrm{H}_{2} \mathrm{~L}$ is a potent $\mathrm{N}_{2} \mathrm{O}_{3}$ pentadentate ligand, only the two symmetrical azomethine systems could coordinate metal ions and this compound finally acts as a $\mathrm{N}_{2} \mathrm{O}_{2}$ tetradentate ligand.

In the complex (2), the cobalt ions show an octahedral environment (Figure 3). Two water molecules are located outside the complexes and four molecules are bounded to the metal ions. These two types of molecules lead to the two endothermic peaks at 159 and $188^{\circ} \mathrm{C}$ observed in the d.s.c. diagram. This feature is also correlated with the shape of the $\mathrm{O}-\mathrm{H}$ stretching band in the infrared spectrum (Sanmartin et al., 2001).

The cupric species (3) shows a typical distorted octahedral geometry. The presence of outer water molecule is confirmed by the exothermic peak at $133^{\circ} \mathrm{C}$ in the d.s.c. diagram as well as the shape of the $v(\mathrm{O}-\mathrm{H})$ vibration band (Boca et al., 2003).

The zinc complex (4) is a binuclear halogen bridging species: $\left[\mathrm{Zn}_{2} \mathrm{Cl}_{2}\left(\mathrm{H}_{2} \mathrm{~L}\right)\right]$. The infrared spectrum show a broad band corresponding to the hydroxyl stretching vibration and in the ${ }^{1} \mathrm{H}$ NMR spectra, the signal at 13.1 p.p.m. remains 


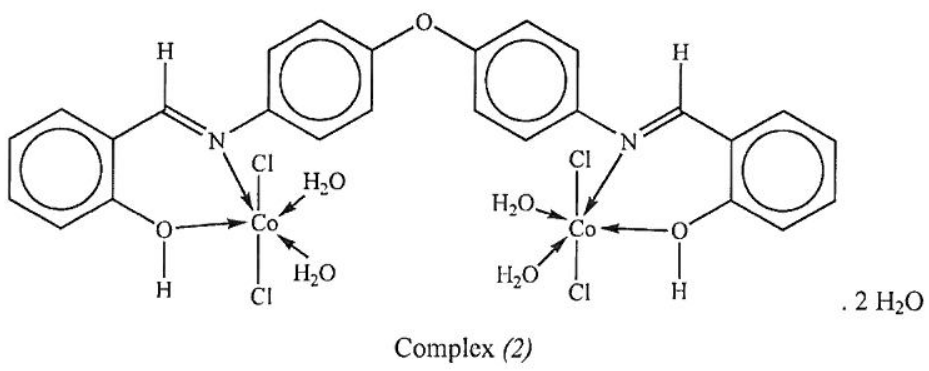<smiles>Oc1ccccc1/C=N/c1ccc(Oc2ccccc2/C=N\c2ccccc2O)cc1</smiles>

Complex (3)

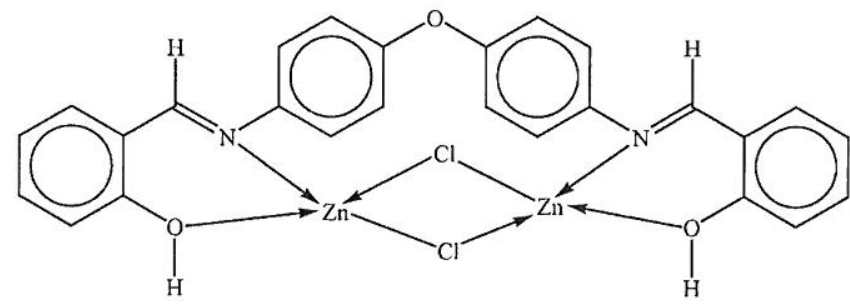

Complex (4)<smiles>Oc1ccccc1/C=N/c1ccc(Oc2ccccc2/C=N\c2ccccc2O)cc1</smiles>

Complex (5)

FIG. 3. Proposed structures for the complexes.

quite unchanged when passing from the ligand to the complex and consequently the phenolic hydroxyl is not ionised. The number of relative proton is less than 2 as it has been observed in cobalt(II) complexes (Felicio, 2001). The molecule is very stable without any thermal phenomenon under $320^{\circ} \mathrm{C}$ in d.s.c. study. The two $\mathrm{Zn}(\mathrm{II})$ ions present a tetrahedral geometry.

The cadmium complex (5) $\left[\mathrm{Cd}\left(\mathrm{H}_{2} \mathrm{~L}\right)\right] \mathrm{Cl}_{2}$ shows a tetrahedral arrangement around the cadmium ion with two chloride ions in the outer sphere of the complex. In the NMR spectra, the phenolic protons give a singulet at 13.1 p.p.m. like in ligand with a slightly modified intensity, like in zinc complex (4).

\section{EXPERIMENTAL}

\section{Chemicals}

All reagents and solvents were analytical grade and used without further treatment.

\section{Physical Measurements}

The measurements were done as previously described (Haffar et al., 2004). The ${ }^{1} \mathrm{H}$ NMR spectra were recorded using a Bruker Avance DRX $500 \mathrm{MHz}$ spectrometer (Service Commun d'Analyses Spectroscopiques, Université d'Angers). 


\section{Synthesis of the Ligand}

The ligand was prepared according to the methods previously reported by Sharma (Yudhuir, 1994) and Gili (1996) by mixing 4,4'-diamino diphenylether and salicyladehyde in $\mathrm{MeOH}$ at $50^{\circ} \mathrm{C}$ in a $1: 2$ ratio. The product was recrystallised from $\mathrm{MeOH}-\mathrm{CHCl}_{3}(50 \% \mathrm{~V} / \mathrm{V})$. The main analytical data are reported in Table 1; they are in good agreement with that previously described (Yoshida et al., 1999).

\section{Synthesis of the Complexes}

To a solution of $1 \mathrm{mmole}$ of the ligand $\left(\mathrm{CHCl}_{3}, 40 \mathrm{~mL}\right)$ was added drop-wise a solution of 1 mmole of the hydrated chlorides $(\mathrm{EtOH}, 10 \mathrm{~mL})$. After heating at $50^{\circ} \mathrm{C}$ for $7 \mathrm{~h}$, the solution was kept at room temperature for a night. Then the complexes precipitated down and were removed by filtration, washed with a hot mixture of methanol and chloroform $(60 / 40 \mathrm{~V} / \mathrm{V})$. Their purity was verified using t.l.c. with toluene $/ \mathrm{EtOH}(50 / 50 \mathrm{~V} / \mathrm{V})$ as solvent. They were finally dried under reduced pressure.

\section{CONCLUSION}

We have described four new complexes obtained with $4,4^{\prime}$-bis(salicyleneimino) diphenyl ether. This compound is a $\mathrm{N}_{2} \mathrm{O}_{3}$ Schiff base but acts as a $\mathrm{N}_{2} \mathrm{O}_{2}$ tetradentate ligand towards cobalt(II), copper(II), zinc(II) and cadmium(II) ions. In every case, the coordination occurs through the $\mathrm{N}$ azomethine atom and the oxygen atom of the phenolic hydroxyl, which is not ionised. Each complex presents its own structure. The cobalt and the zinc species are binuclear while cooper and cadmium complexes are mononuclear. Only $\mathrm{Co}(\mathrm{II})$ and $\mathrm{Cu}(\mathrm{II})$ compounds are hydrated species.

\section{REFERENCES}

Aguilar-Martinez, M.; Saloma-Aguila, R.; Macias-Ruvalcaba, N.; Cetina-Rosado, R.; Navarrete-Vázquez, A.; Gómez-Vidales, V.; Zentella-Dehesa, A.; Toscano, R. A.; Hernández-Ortega, S.; Fernández-G, J. M. Synthseis, crystal structures, spectroscopic ans electrochemical properties of homolgous series of copper(II) complexes of Schiff bases derived from cycloalkylamines. J. Chem. Soc. Dalton Trans. 2001, 2346-2352.

Anderson, C. W.; Lung, K. R.; Nile, T. A. Electrochemistry of homogeneous catalysts: correlation of the electrochemistry and the ziegler-natta catalytic activity of metal acetyacetonate complexes. Inorg. Chim. Acta 1984, 85, 33-36.

Ando, R.; Mori, S.; Hayashi, M.; Yagyu, T.; Maeda, M. Structural characterization of pentadentate salen-type Schiff-base complexes of oxovanadium(IV) and their use in sulfide oxidation. Inorg. Chim. Acta 2004, 357, 1177-1184.

Boča, M.; Valko, M.; Kickelbick, G.; Durik, M.; Linert, W. Cu ${ }^{\text {II }}$ complexes with the new Schiff base ligands as a mono- and bis-condensation products of 2-pyridinecarboxaldehyde- $\mathrm{N}$-oxide with diethylenetriamine. Inorg. Chim. Acta 2003, 349, 111-122.

Bouet, G. M.; Ibrahim, G.; Khan, M. A. Metallic complexes with furan oximes. V. Synthesis and characterization of 5-nitro 2- furfuraldoxime complexes with $3 \mathrm{~d}$ element dihalides. Trans. Met. Chem. 1996, 21, 530-535.

Djebbar-Sid, S.; Benali-Baïtich, O.; Deloume, J. P. Synthesis, characterization and electrochemical behaviour of cobalt(II) and cobalt(III $: \mathrm{O}_{2}^{-}$complexes, respectively, with linear and tripodal tetradentate ligands derived from Schiff bases. J. Mol. Struct. 2001, 569, 121-128.

Djebbar-Sid, S.; Benali-Baïtich, O.; Deloume, J. P. Synthesis, characterization and electrochemical behaviour of some copper(II) complexes with linear and tripodal tetradentate ligands derived from Schiff bases. Polyhedron 1997, 16, 2175-2182.

Feiffer, P.; Breith, E.; Lubbe, E.; Tsumaki, T. Tricyclic ortho-condensed partial valence rings. Ann. 1933, 84-130.

Felicio, R. C.; Cavlaheiro, E. T. G.; Dockal, E. R. Reparation, characterization and thermogravimetric studies of $\left[\mathrm{N}, \mathrm{N}^{\prime}\right.$-cis-1,2-cyclohexylene bis(salicylideneaminato) $]$ cobalt(II) and $\left[\mathrm{N}, \mathrm{N}^{\prime}-( \pm)-\right.$ trans-1,2-cyclo-hexylene bis(salicylideneaminato)]cobalt(II). Polyhedron 2001, 20, 261-268.

Fernandez-G, J. M.; Lopez-Duran, F. A.; Hernades-Ortega, S.; Gomez-Vidales, V.; Macias-Ruvalcaba, N.; Aguilar-Martinez, M. The structures and cyclic voltammetry of three copper(II) complexes derived from bulky ortho-hydroxy Schiff bases. J. Mol. Struct. 2002, 612, 69-79.

Gili, P.; Reyes, M. G. M.; Zarza, P. M.; Machado, I. L. F.; Pombeiro, A. J. L. Synthesis, spectroscopic, magnetic and electrochemical properties of $\mathrm{Cu}$ (II) and $\mathrm{Fe}$ (III) complexes with the new ligand $\mathrm{N}, \mathrm{N}^{\prime}$-[1,1'-dithiobis(phenyl)]bis(5'-methoxysalicylaldimine). Inorg. Chim. Acta 1996, 244, 25-36.

Gullotti, M.; Pasini, A.; Fantucci, P.; Renato, U.; Gillard, R. D. Optically active complexes of Schiff bases. I. Syntheses and properties of optically active tetradentate Schiff bases. Gazz. Chim. Ital. 1972, 855-892.

Haffar, D.; Douadi, T.; Chafaa, S.; Khan, M. A.; Bouet, G. Synthesis, characterisation and electrochemical study of 4,4'-bis(salicylideneimino) diphenylethane and its complexes with cobalt(II), copper(II) and cadmium(II). Trans. Met. Chem. 2004, 29, 245-250.

Karipcin, F.; Ismet-Ucan, H.; Karatas, I. Binuclear and mononuclear cobat(II), nickle(II) and copper(II) complexes of 4,4'-bis(alkylaminoisonitroacetyl)diphenyl-methane derivatives. Trans. Met. Chem. 2002, 27, 813-817.

Keypour, H.; Khanmohammadi, H.; Wainwright, K. P.; Taylor, M. R. Synthesis and crystal structure determination of some novel zinc(II) macrocyclic heptaaza Schiff-base complexes with two 2-aminoethyl pendant arms. Inorg. Chim. Acta 2003, 355, 286-291.

Keypour, H.; Khanmohammadi, H.; Wainwright, K. P.; Taylor, M. R. Synthesis, crystal structure, NMR and ab initio molecular-orbital studies of some magnesium(II) macrocyclic Schiff-base complexes, with two 2-aminoethyl pendant arms. Inorg. Chim. Acta 2004, 357, 1283-1291.

Keypour, H.; Salehzade, S.; Parish, R. V. Synthesis of two potentially heptadentate (N4O3) Schiff-base ligands derived from condensation of Tris(3-aminopropyl)-amine and Salicylaldehyde or 4-Hydroxysalicylaldehyde. Nickel(II) and Copper(II) complexes of the former ligand. Molecules 2002, 7, 140-144.

Lutta, S. T.; Kagwanja, S. M. Synthesis and electrochemical studies of heterobinuclear zinc and molybdenum mononitrosyl complexes 
linked by Schiff base ligands. Transition Met. Chem. 2001, 26, 523-527.

Nicholson, R.; Schain, I. Theory of stationary electrode polarography. single scan and cyclic methods applied to reversible, irreversible, and kinetic systems. Anal. Chem. 1964, 36, 706-723.

Pereira, E.; Gomes, L.; De Castro, B. Synthesis, spectroscopic and electrochemical study of nickel(II) complexes with tetradentate asymmetric Schiff bases derived from salicylaldehyde and methyl-2-amino-1-cyclopentenedithiocarboxylate. Inorg. Chim. Acta 1998, 271, 83-92.

Ramachandraiah, A.; Rao, P. N.; Ramaiah, M. Synthesis and characterization of copper(II), nickel(II), cobalt(II), and dioxouranium(VI) complexes of a new series of tetradentate binucleating Schiff base ligands. Ind. J. Chem. Sect. A. 1989, 309-313.

Raman, N.; Kulandaisamy, A.; Shunmugasundaram, A.; Jeyasubramanian, K. Synthesis, spectral, redox and antimicrobial activities of Schiff base complexes derived from 1-phenyl-2,3-dimethyl-4aminopyrazol-5-one and acetoacetanilide. Trans. Met. Chem. 2001, 26, 131-135.

Samal, S.; Acharya, S.; Dey, R. K.; Ray, A. R. Synthesis and metal ion uptake studies of chelating resins derived from formaldehydefurfuraldehyde condensed phenolic Schiff bases of 4,4' diaminodiphenylether and o-hydroxyacetophenone. Talanta 2002, 57, 1075-1083.

Sanmartin, J.; Bermejo, M. R.; Garcia-Deibe, A. M.; Nascimento, O. R.; Costa-Filho, A. J. Co(II), Ni(II) and $\mathrm{Cu}(\mathrm{II})$ mononuclear and polynuclear complexes influenced by the aliphatic spacer length of their $\mathrm{O} 2 \mathrm{~N} 2 \mathrm{O} 2$ Schiff bases. Inorg. Chim. Acta 2001, 318, 135-142.

Sanmartin, J.; Bermejo, M. R.; Garia-Deibe, A. M.; Maneiro, M.; Lage, C.; Costa-Filho, A. J. Mono- and polynuclear complexes of $\mathrm{Fe}(\mathrm{II}), \mathrm{Co}(\mathrm{II}), \mathrm{Ni}(\mathrm{II}), \mathrm{Cu}(\mathrm{II}), \mathrm{Zn}(\mathrm{II})$ and $\mathrm{Cd}(\mathrm{II})$ with $\mathrm{N}, \mathrm{N}^{\prime}-$ bis(3-hydroxysalicylidene)-1,3-diamino-2-propanol. Polyhedron 2000, 19, 185-192.

Wilkinson, G. Comprehensive Coordination Chemistry; Pergamon Press: Oxford, 1987; pp. 166-494.

Yoshida, N.; Oshio, H.; Ito, T. Copper(II)-assisted self-assembly of bis-N,O-bidentate Schiff bases: new building blocks for a double-helical supramolecular motif. J. Chem. Soc. Perkin Trans. 1999, 2, 975-984.

Yudhvir, S. S.; Pandey, H. N.; Mathur, P. Monomeric and dimeric copper(II) complexes of a redox active Schiff base ligand bis(2,5-dihydroxyacetophenone) ethylenediamine. Polyhedron 1994, 13, 3111-3117. 